\title{
Hubungan Kapitalisme dan Produksi
}

\author{
Rezki Amalia Fathurrahman (90100118108) \\ Email: rezkiamalia56@gmail.com
}

\begin{abstract}
Abstrak
Di dunia jumlah kekayaan diseluruh dunia adalah 359 orang terkaya didunia yang setara dengan jumlah kekayaan 2,9 Miliar orang-orang termiskin didunia. Yang dimana terdapat 5 Miliar penduduk di bumi yang terdapat orang kaya hanya 359 orang jika di rata-ratakan kekayaan mereka sama dengan jumlah kekayaan separuh dari jumlah penduduk di bumi. Misalkan jika 3 orang kaya di dunia bila digabungkan dengan sama dengan GDP 48 negara miskin. Maka dari itu untuk mengatasi permasalahan penduduk di dunia seperti ketersediaan kebutuhan makanan, air, pendidikan dan kesehatan serta mengatasi kelaparan, kekurangan gizi dan wabah penyakit, maka dibutuhkan adalah 4\% dari akumlasi kekayaan dari 255 orang terkaya di dunia. Agar bisa memenuhi kebutuhan seperti kesehatan dan makanan maka biaya yang diperlukan sebesar $\$ 13$ Miliar yang jika dihitung setara dengan pengeluaran pembelian parfum di Eropa. Sehingga Fakta di atas bisa disimpulkan bahwa terjadinya kesenjangan apa itu dari pendapatan atau kekurangan kebutuhan pokok. Dan juga terjadi kontradiksi yang terjadi di masyarakat karena di tengah kesejahteraan dan kekayaan ternyata kemiskinan masih terjadi sehingga terjadi reproduksi kemiskinan dan kesengsaraan yang terus menerus terjadi. Kehidupan masyarakat yang alami saat ini yang disebut dengan kapitalisme. Yang dimana kapitalisme adalah suatu sistem ekonomi sosial yang bercirikan kepada profit motive atau keuntungan yang dikontrol oleh sarana produksi, distribusi dan petukaran dan kepemilikan pribadi.
\end{abstract}

Kata Kunci: Kapitalisme; Produksi; Distribusi 


\section{Pendahuluan}

Kapitalisme menurut Weber, adalah suatu sistem ekonomi yang tumbuh dan berkembang karena tujuannya hanya mencari keuntungan ekonomi secara rasional maksudnya kapitalisme ini hanya mencari keuntungan dengan mengandalkan modal dan kepemilikan sarana produksi (Rochwulaningsih, 2007). Maka dari itu kaum kapitalis ini melakukan akumulasi dengan melakukan penghematan dan investasi modal sebagai kunci pertumbuhan ekonomi (Atmanti, 2017). Maka dari agar pertumbuhan ekonomi meningkat diperlukan penggunaan modal yang secara besarbesaran dalam melakukan produksi dan kebebasan besar dalam melakukan usaha yang bekerjasama perusahaan swasta raksasa yang berbentuk perseroan sedang tumbuh dan berkembang walaupun kadang dituding sebagai penyebab kesenjangan kesejahteraan dalam masyarakat, karena kaum produsen atau pemiliki cenderung mengeksploitasi kaum buruh (Fuadi, 2015). Untuk produksi dilakukan dua cara yaitu adanya tenaga kerja yang memiliki peranan penting dalam untuk menghasilkan komoditas atau barang (Saptana et al., 2016) 


\section{Pembahasan}

Kapitalisme adalah suatu sistem ekonomi yang memberikan kebebasan kepada setiap individu untuk melakukan kegiatan ekonomi dengan modal dan sarana produksi yang dimiliki, adapun ciri-ciri kapitalisme adalah, ada pengakuan atas hak pribadi kepemilikan, adanya mekanisme pasar dan perekonomian yang digerakkan karena ada motif mencari keuntungan (Subandi, 2018). Agar produksi berjalan dengan baik maka menurut Ibnu Khaldun harus memiliki tenaga kerja karena dengan tenaga kerja maka segala kegiatan produksi bisa berjalan sebagaimana mestinya dan tenaga manusia adalah akumulasi dari keuntungan dan modal jika tenaga kerja bisa di tambahkan (Adiwarman Azwar Karim, 2017). Menurut David Ricardo produksi juga akan berjalan baik jika melakukan jika suatu negara melakukan spesialisasi atau pembagian kerja yang nanti memberikan keuntungan absolut atau mutlak pada produk tertentu (Faruq \& Mulyanto, 2017). Setelah itu hasil produksinya nantinya akan diekspor komoditas tersebut lebih murah dan untuk impor lebih mahal dari penggunaan sumber daya (Yusdja, 2016).

Faktor-faktor produksi yang diperlukan adalah memiliki sumber daya alam, tenaga kerja, memiliki modal serta manajemen yang baik (Fadilah, 2017). Adapun rumusnya M-C-M' ditambahkan LP dan MP akan menghasilkan proses produksi maksudnya $\mathrm{M}$ adalah uang yang digunakan untuk membeli komoditas dengan simbol C yang nanti akan menghasilkan keuntungan $M^{\prime}$ untuk digunakan sebagai modal, agar terjadi keuntungan dan produksi meningkat maka diperlukan tenaga kerja (labour power) dan sarana produksi (means of produksi) untuk melakukan proses keuntungan

yang nanti akan menghasilkan keuntungan lalu dijual kembali. Setelah selesai produksi komoditas lalu hasil komoditas kemudian dibagikan kepada masyarakat yang membutuhkan agar kebutuhannya terpenuhi (Sirajuddin, 2016) 


\section{Kesimpulan}

Terjadi kesenjangan sosial karena adanya kontradiksi antara kekayaan dan kesejahteraan yang terkadang ketika ada pembangunan selalu bersama dengan terjadi kemiskinan. Hal yang di alami masyarakat ini yang disebut dengan kapitalisme adalah suatu sistem ekonomi yang memberikan kebebasan kepada setiap individu untuk melakukan kegiatan ekonomi dengan modal dan sarana produksi yang dimiliki. Dan untuk kegiatan produksi agar berjalan maka perlu adanya tenaga kerja, modal, dan sarana produksi yang nanti akan menghasilkan komoditas yang kemudian di ekspor atau di impor hasil komoditas tadi. 


\section{Daftar Pustaka}

Adiwarman Azwar Karim. (2017). Sejarah Pemikiran Ekonomi Islam (4th ed.). Rajawali Pers.

Atmanti, H. D. (2017). Kajian Teori Pemikiran Ekonomi Mazhab Klasik dan Relevansinya pada Perekonomian Indonesia. Jurnal Ekonomi \& Bisnis, 2(2), 511524. http://jurnal.untag-sby.ac.id/index.php/JEB17/article/view/1140

Fadilah, N. (2017). Aktivitas Produksi Kapitalis Dalam Perspektif Ekonomi Islam. AnNisbah: Jurnal Ekonomi Syariah, 4(1). https://doi.org/10.21274/an.2017.4.1.147170

Faruq, U. Al, \& Mulyanto, E. (2017). Sejarah Teori-Teori Ekonomi (Issue 1). UNPAM PRESS.

Fuadi, A. (2015). Negara Kesejahteraan (Welfare State). JESI JUrnal Ekonomi Syariah Indonesia,

$5(1)$.

http://ejournal.almaata.ac.id/index.php/JESI/article/download/190/185

Rochwulaningsih, Y. (2007). Petani Garam dalam Jeratan Kapitalisme : Analisis Kasus Petani Garam di Rembang, Jawa Tengah. Jurnal Masyarakat, Kebudayaan Dan Politik, 20(3), 228-239.

Saptana, N., Sunarsih, N., \& Indraningsih, K. S. (2016). Mewujudkan Keunggulan Komparatif Menjadi Keunggulan Kompetitif Melalui Pengembangan Kemitraan Usaha Hortikultura. Forum Penelitian Agro Ekonomi, 24(1), 61. https://doi.org/10.21082/fae.v24n1.2006.61-76

Sirajuddin. (2016). Konsep Pemikiran Ekonomi Al-Ghazali. Laa Maisyir, 3(1), 46-60.

Subandi. (2018). Sistem Ekonomi Indonesia. Alfabeta.

Yusdja, Y. (2016). Tinjauan Teori Perdagangan Internasional dan Keunggulan Kooperatif. Forum Penelitian Agro Ekonomi, 22(2), 126. https://doi.org/10.21082/fae.v22n2.2004.126-141 